\title{
Wage Restraint, Employment, and the Legacy of the General Theory's Chapter 19
}

\author{
Oliver Landmann \\ University of Freiburg i.Br.
}

\section{Introduction}

The role of wages in the determination of aggregate employment remains one of the most hotly debated public policy issues in many European countries, and in Germany in particular. This is not surprising in view of the high-profile collective bargaining process in which organized labor and employers negotiate over wages under conditions of persistent high unemployment. Of course, neither side wishes to be seen as merely pursuing its narrow self-interest. Both employers and unions make every effort to argue as convincingly as possible that their respective bargaining positions are conducive to employment growth and macroeconomic stability. Employers invoke neoclassical labor market theory to reject any demands for wage increases in excess of labor productivity growth. Such wage increases, they argue, mean rising labor costs and hence cause job losses. Unions, in contrast, emphasize demand-side repercussions and appeal to the keynesian notion of the circular flow of income. They maintain that any attempt to boost employment through wage restraint is doomed to fail, mainly because this would reduce the purchasing power of consumers and thus domestic demand. Accordingly, they tend to put the blame for high unemployment on misguided fiscal and monetary policies. In contrast, the mainstream consensus regards the longer-term trends of output and employment as supply-determined and, therefore, rejects demand-side explanations of unemployment, except for the very short-run cyclical movements.

Keynes (1936) devoted an entire chapter of his General Theory, the famous Chapter 19, to the macroeconomic effects of changes in money-wages. He identified no less than seven transmission channels through which a fall in the nominal wage level might affect employment, most prominently among them the real balance effect that got to be known as 'Keynes effect' in generations of macroeconomics textbooks. His well known conclusion was that nominal wage 
flexibility cannot be relied upon to maintain a stable state of high employment, but might rather be a source of undesirable price level instability.

Obviously, this conclusion did not go uncontested and has remained controversial ever since. But can those who reject wage moderation and labor market deregulation as cures for unemployment today really base their case on Keynes? Is Keynes's reasoning still relevant to the modern debate and current labor markets? Do we understand the effects of wage policy any better today than he did in 1936? This paper offers some reflections on these questions. It does so by embedding the major points made by Keynes in Chapter 19 into different models that reflect the evolution of keynesian thinking on macroeconomic theory and policy over time.

We start in section 2 with an analysis of the purchasing power argument using a variant of the static textbook aggregate-supply/aggregate-demand framework. Subsequently, section 3 considers the implications of endogenizing the nominal wage level under alternative assumptions on the behavior of monetary policy. Some open-economy issues are also briefly addressed. Section 4 sums up and concludes.

\section{The purchasing power paradox of wages}

As pointed out above, the case against wage restraint as a cure for unemployment is based most importantly on the idea that falling wages or, for that matter, wages lagging behind productivity growth reduce domestic demand relatively to the productive capacity of the economy, which could harm employment if output is demand-determined. The keynesian origin of this line of argument can be traced back, of course, to Chapter 19 of the General Theory ( $\mathrm{p}$. 262):

"A reduction of money-wages will somewhat reduce prices. It will, therefore, involve some redistribution of real income (a) from wage earners to other factors entering into marginal prime cost whose remuneration has not been reduced, and (b) from entrepreneurs to rentiers... The transfer from wage earners to other factors is likely to diminish the propensity to consume."

In the standard textbook representation of the static keynesian model, a reduction of the money-wage unambiguously raises employment due to the operation of the Keynes effect. Does this result survive if, in addition, we take account of a "diminished propensity to consume" due to a loss of purchasing

This section draws on Jerger/Landmann (forthcoming). 
power on the part of wage earners? A simple model may help to clarify the issue. Consider the following log-linear relationships linking output, employment and the price level to the nominal wage level, the money supply and aggregate labor productivity:

$$
\begin{aligned}
& y=c+\alpha n ; \quad \alpha<1 \\
& p=\varphi+w-c+(1-\alpha) n \\
& y=\beta_{0} g+\beta_{1}(m-p)+\beta_{2}(w+n-p) ; \quad \beta_{2}<\alpha,
\end{aligned}
$$

Equation (1) is a production function linking the log of output $y$ to the log of employment $n$. The intercept $c$ captures exogenous determinants of labor productivity such as capital accumulation and technical progress. Thus, the rate of change of $c(d c / d t)$ can be interpreted as trend productivity growth. Equation (2) represents the log of the price level $p$ as determined by the price setting behavior of imperfectly competitive firms. Here, $w$ is the log of the money-wage, $w-c+(1$ $-\alpha) n$ is the $\log$ of unit labor cost and $\varphi$ is a mark-up factor reflecting technology and market structure. The agregate demand function (3) allows for a purchasing power effect of wages by including the log of the real wage bill $(w+n-p)$ as an additional explanatory variable, along with the log of the real money supply $(m-p)$ and the log of real autonomous demand $g$. All parameters in equations (1) to (3) are non-negative.

The underlying logic of the model is very simple: Firms set prices on the basis of their wage costs, they meet the demand forthcoming at those prices, and they employ labor as required by the resulting level of output. We can solve the model for output, employment and the price level (ignoring the exogenous mark-up factor $\phi)$ :

$$
\left[\begin{array}{l}
y \\
n \\
p
\end{array}\right]=\Delta^{-1} \cdot\left[\begin{array}{cccc}
\alpha \beta_{1} & -\alpha \beta_{1} & \beta_{1} & \alpha \beta_{0} \\
\beta_{1} & -\beta_{1} & \beta_{1}+\beta_{2}-1 & \beta_{0} \\
\beta_{1}(1-\alpha) & \alpha\left(1-\beta_{2}\right) & \beta_{2}-1 & \beta_{0}(1-\alpha)
\end{array}\right] \cdot\left[\begin{array}{c}
m \\
w \\
c \\
g
\end{array}\right],
$$

where $\Delta \equiv \alpha\left(1-\beta_{1}-\beta_{2}\right)+\beta_{1}>0$

Three properties of this solution appear noteworthy:

1. A fall in the nominal wage level unambiguously raises employment although the demand function allows for a purchasing power effect of wages. The purchasing power effect thus cannot dominate the Keynes effect. Quite to the contrary, and perhaps surprisingly, the purchasing power effect turns out to strengthen the inverse relationship between employment and nominal wages, in the sense that the absolute value of $d n / d w$ is increasing in $\beta_{2}$. This result can in 
turn be traced to a property one might call the purchasing power paradox of wages:

2. A fall in the nominal wage level unambiguously raises the real aggregate purchasing power of wage earners. This can be seen by solving (4) for $d(w+n-p) / d w<0$. The pass-through of the nominal wage change to the price level plus the inverse response of employment are strong enough together to outweigh the initial wage change as long as $\beta_{l}>0$. Even in the limiting case $\beta_{l}=0$ where the Keynes effect is absent, a fall in nominal wages does not reduce the real purchasing power of wage earners because in that case the price level falls by the same amount as the wage level. This scenario confirms Keynes's suspicion that "there may exist no expedient by which labour as a whole can reduce its real wage to a given figure by making revised money bargains with the entrepreneurs" (Keynes 1936, p. 13).

3. The behavior of the nominal wage level relatively to trend productivity growth is not the key to the behavior of employment. In particular, and in contrast to a widely held view, wage bargains that keep the rate of growth of wages below the rate of growth of trend productivity $(d w / d t<d c / d t)$ are neither sufficient nor necessary for an expansion of employment. After all, according to (4), employment depends on the demand variables $m$ and $g$ as well as on the money wage $w$ whereas the role of trend productivity (the sign of $d n / d c$ ) is unclear. Thus, an increase in employment requires suitably coordinated wage and demand policies. More precisely, employment is proportional to the ratio of nominal aggregate demand and the nominal wage level - as (1) and (2) imply $n=p+y$ $w-\varphi$.

In sum, the notion that a case against the employment-enhancing effect of wage restraint can be built on the purchasing power effect of wage changes finds no support in static keynesian theory.

\section{Beyond the static model}

The static keynesian model was designed to demonstrate the possibility of an unemployment equilibrium, which was arguably the most revolutionary theoretical innovation of the General Theory. However, the logic of the unemployment equilibrium came under attack very soon, even from theorists who fully agreed with Keynes that the market system lacked adequate self-stabilizing forces. For the concept of an unemployment equilibrium crucially hinged on Keynes's methodological working hypothesis that "the wage-unit as determined by the bargains reached between employers and employed" could reasonably be regarded as one of "our ultimate independent elements" (Keynes 1936, p. 246-47) - that is, as an exogenous variable, to put it in more contemporary language.

\footnotetext{
Emphasis in the original.
} 
Responding to Pigou's critique of the unemployment equilibrium and the liquidity trap, Patinkin (1948) was one of the first to argue that the proper focus of the keynesian attack against the classical theory should not be to prove the possibility of an equilibrium in the absence of full employment, but rather to highlight the lack of dynamic stability plaguing the economic system when it is in disequilibrium - its inability to return back to full employment within reasonable time after being driven away from equilibrium by an exogenous shock. ${ }^{3} 20$ years later, the challenge to the keynesian theory became even sharper with the PhelpsFriedman model of the natural rate of unemployment. Again, the Keynesians after some initial resistance - surrendered relatively soon and redirected their attention towards the dynamic properties of the system in disequilibrium.

An influential contribution along these lines was Tobin's (1975) demonstration that the standard dynamic model used by monetarists to trace out the convergence of the unemployment rate to its natural level, such as the one presented by Laidler and Parkin (1975), was potentially unstable. The central mechanism driving unemployment in the monetarist model was a real balance effect quite akin to the Keynes effect of Chapter 19, except that it did not result from exogenous wage changes, but from the interaction of an exogenous growth path of the money supply with the endogenous wage-price dynamics generated by an expectations augmented Phillips curve. Dissecting the monetarist model, Tobin took a closer look at the dynamic effects of inflation and deflation on effective demand and in the process revived yet another important idea from Chapter 19. Keynes had argued that, even though a low wage might be associated with higher employment than a high wage in a comparative static context, the wage deflation needed to get from the one to the other is itself detrimental to effective demand:

"The most unfavourable contingency is that in which money-wages are slowly sagging downwards and each reduction in wages serves to diminish confidence in the prospective maintenance of wages... For example, the effect of an expectation that wages are going to sag by, say, 2 percent in the coming year will be roughly equivalent to the effect of a rise of 2 percent in the amount of interest payable for the same period."

\section{A natural rate model}

Following the spirit of Tobin's (1975) analysis, we can formally model the countervailing demand-side effects of the price level and its rate of change in a dynamic setting which combines an expectations augmented Phillips curve with a standard IS-LM framework:

\footnotetext{
In Chapter 19 of the General Theory, Keynes actually came close to making this point himself.

${ }^{4}$ Keynes (1936), p. 265.
} 
6

(5) $y=\gamma_{0} g-\gamma_{1} r$

(6) $\quad m-p=\delta_{0} y-\delta_{1} i$

(7) $\quad r \equiv i-\pi^{e}$

(8) $\pi=-\varepsilon_{0}+\varepsilon_{1} y+\pi^{e} \equiv \varepsilon_{1}(y-\bar{y})+\pi^{e} ; \quad$ where $\bar{y}=\varepsilon_{0} / \varepsilon_{1}$

(9) $\quad d \pi^{e} / d t=\zeta\left(\pi-\pi^{e}\right)$

(10) $d m / d t=\mu$

Again, the parameters are non-negative and the variables, except for the interest rates, are logs. The IS equation (5) now ignores an purchasing power effects of wages. The crucial feature of the IS-LM building block is the standard assumption that the demand for output in (5) depends on the real interest rate $r$ whereas the demand for money in the LM condition (6) depends on the nominal interest rate $i$. The two interest rates are linked by the identity (7). The Phillips curve (8) summarizes the process of wage formation and the pass-through of wages to prices in one equation linking the inflation rate $\pi(\equiv d p / d t)$ to output and expected inflation $\pi^{\mathrm{e}}$. Natural output $\bar{y}=\varepsilon_{0} / \varepsilon_{1}$ is defined by the condition $\pi=\pi^{\mathrm{e}}$. The expected inflation rate is assumed to change over time according to the adaptive expectations hypothesis (9). This old-fashioned hypothesis on the formation of expectations is chosen here not only because it was used by Tobin (1975), but also because it provides a convenient way of representing inflation inertia. Contrary to what Tobin suspected at the time, nothing much changes if one assumes rational expectations instead - provided that inflation inertia is introduced in some other way. ${ }^{5}$ Finally, equation (10) introduces the assumption of a constant money growth rate $\mu$.

Equations (5) - (7) can be condensed into an aggregate demand function which is noteworthy for including expected inflation as an argument:

$$
\begin{aligned}
& y=\beta_{0} g+\beta_{1}(m-p)+\beta_{3} \pi^{e} \\
& \text { where } \beta_{0} \equiv \gamma_{0} \beta_{4} ; \beta_{1} \equiv \gamma_{1} \beta_{4} / \delta_{1} ; \beta_{3} \equiv \gamma_{1} \beta_{4} ; \beta_{4} \equiv \delta_{1}\left(\delta_{1}+\gamma_{1} \delta_{0}\right)^{-1}
\end{aligned}
$$

Assuming constant $g$ and $\bar{y}$, equations (8) and (9) can be combined with the time derivatives of (3') and (8) to derive the following dynamics for output and inflation:

\footnotetext{
See Landmann/Jerger (1999), pp 110-14, for a discussion of this point.
} 


$$
\left[\begin{array}{l}
d \pi / d t \\
d y / d t
\end{array}\right]=\left[\begin{array}{cc}
-\beta_{1} \varepsilon_{1} & \varepsilon_{1} \zeta\left(1+\beta_{3} \varepsilon_{1}\right) \\
-\beta_{1} & \beta_{3} \varepsilon_{1} \zeta
\end{array}\right] \cdot\left[\begin{array}{c}
\pi-\mu \\
y-\bar{y}
\end{array}\right]
$$

It is straightforward to establish the equilibrium conditions $y=\bar{y}$ and $\pi=\mu$. In the context of this model, wage restraint is best understood as a change in the wage formation process - be it due to an autonomous change in the behavior of wage setters or due to some labor market reform inducing them to change their behavior - such that the rate of wage increase negotiated at any given unemployment rate (or output level) is reduced. Wage restraint is thus tantamount to an increase in $\varepsilon_{0}$ and, therefore, to an increase in natural output, which in turn implies a fall of the natural rate of unemployment although this is not made explicit by the model. Moreover, as Phelps (1967) and Friedman (1968) famously demonstrated, monetary policy cannot be used to control the equilibrium levels of output and employment. ${ }^{6}$

Tobin pointed out that even if one believed the model and its equilibrium conditions (which he was prepared to do for the sake of the argument), the equilibrium is not necessarily stable. Evidently, the stability of the dynamic system (11) requires $\beta_{1}>\beta_{3} \zeta$, which means that the stabilizing real balance effect in the demand equation is strong enough to outweigh the destabilizing inflation expectations effect. Tobin argued that this cannot be taken for granted, especially in a deep recession when the interest elasticity of money demand is high (and $\beta_{l}$ accordingly low).

What are the effects of wage restraint in this model? As pointed out above, the natural rate of output must increase whereas the equilibrium inflation rate is not affected as long as money growth remains unchanged. The dynamic response of the economic system to the change in the wage formation process is illustrated by the phase diagram in Figure 1. $E_{0}$ denotes the initial equilibrium, $E_{l}$ is the new equilibrium after the exogenous change. As indicated by the directional arrows, the move which was supposed to increase output and employment sets off a disinflationary spiral with initially falling output. A recovery does not start until the real money supply has been reduced by enough to counterbalance the adverse real interest rate effect of the falling inflation rate - which happens when the trajectory crosses the $d y / d t=0$ line.

Figure 1

\footnotetext{
${ }^{6}$ It is sometimes argued that the inability of demand policies to affect equilibrium output in this model means that the model is inconsistent with the model of the foregoing section in which output depends both on wage and demand policies. But there is no inconsistency, of course, because the static model of section 2 is built on the assumption of a given exogenous money-wage. The static model can be interpreted as providing an instantaneous picture of an economy whose dynamics are represented by the differential equations (11).
} 
Whether or not the oscillatory adjustment path ultimately converges to the new equilibrium $E_{l}$ depends on the stability condition stated above. Even if the system is stable, the basic message of the model is not lost: Wage restraint alone is illsuited to start a swift transition to a higher level of output and employment without support from fiscal or monetary policy. In the absence of such support, unemployment initially gets worse - possibly for an extended period of time. Remarkably, the doubts about the stabilizing power of wage flexibility to which Keynes was led by his analysis in Chapter 19 are confirmed even by a natural rate model.

\section{Endogenizing monetary policy}

The supportive role of active demand management is all the more important as the structural reforms and legislative changes that are required to bring about wage restraint and to make it sustainable are likely to meet fierce resistance in the political arena. It has been pointed out many times that there is considerable scope for political deals involving the promise of an accommodating demand policy in return for a willingness to tolerate the needed institutional reforms. ' Obviously, it is difficult in practice to strike such deals. As game-theoretic treatments of stabilization policy have shown, unions and the central bank can easily get caught in an inefficient Nash equilibrium made up by aggressive wage demands and monetary restriction. ${ }^{8}$ In such a situation, institutional labor market reform and a suitable monetary policy rule might potentially serve as commitment technologies and thereby offer a way out of the deadlock.

Many recent studies of central bank behavior have shown that the assumption of an exogenous growth path for the money supply is an extremely poor chracterization of what central banks actually do - even in the case of those central banks that have explicitly declared to pursue the monetarist strategy of targeting a monetary aggregate. ' Instead, it appears that the interest rate rule proposed by Taylor (1993) offers a surprisingly robust description of actual central bank behavior. The Taylor rule is a feedback rule for the nominal interest rate of the form

$$
i=\pi+\hat{r}+\eta_{0}(y-\bar{y})+\eta_{1}\left(\pi-\pi_{T}\right) ; \quad \eta_{0}, \eta_{1}>0,
$$

where $\hat{r}$ denotes the central bank's best estimate of the equilibrium real interest rate and $\pi_{T}$ is the central bank's target inflation rate. The studies collected in

\footnotetext{
See e.g. Gordon (1996).

\& An early reference is von Weizsäcker (1978).

Recent studies on the behavior of the German Bundesbank include Clarida/Gertler (1997) and Bernanke/Mihov (1997).
} 
Taylor (1999) suggest that the Taylor rule is not only fairly accurate as a factual description of recent monetary policy, but is also quite useful as a normative decision rule. The evaluation of monetary policy rules has developed into a hightech industry involving the estimation of trade-offs between inflation variability and output variability. Here, we study a much more modest analytical question: How do the macroeconomic effects of wage moderation change when monetary policy is guided by the Taylor rule rather than by a constant target rate for money growth?

The analysis of this question involves a straightforward exercise in what Romer (2000) has termed "Keynesian Macroeconomics without the LM Curve". The LM curve becomes dispensable in this variety of macroeconomics because it is no longer needed to determine the interest rate. The latter is directly controlled by the central bank. What is left for the LM equation to do is to determine the money supply which is consistent with the Taylor rule. Combining the IS equation (5) with the Taylor rule (12), and using the definition of the real interest rate in (7), we get an aggregate demand schedule which directly relates output and inflation:

$$
y=\gamma_{0} g-\gamma_{1}\left[\pi+\hat{r}+\eta_{0}(y-\bar{y})+\eta_{1}\left(\pi-\pi_{T}\right)-\pi^{e}\right]
$$

Using the Phillips curve (8) to eliminate the expected inflation term $\pi^{e}$, this can be simplified to

$$
\begin{aligned}
& y=\theta_{0}-\theta_{1} \pi \\
& \text { where } \theta_{0} \equiv \frac{\gamma_{0} g+\gamma_{1}\left[\left(\varepsilon_{1}+\eta_{0}\right) \bar{y}+\eta_{1} \pi_{T}-\hat{r}\right]}{1+\gamma_{1}\left(\varepsilon_{1}+\eta_{0}\right)} ; \quad \theta_{1} \equiv \frac{\gamma_{1} \eta_{1}}{1+\gamma_{1}\left(\varepsilon_{1}+\eta_{0}\right)}
\end{aligned}
$$

This inverse relationship between output and inflation is shown as the downward sloping aggregate demand curve $A D_{0}$ in Figure 2 . Its slope essentially reflects the feedback parameters in the central bank's policy rule and the interest rate elasticity of aggreagte demand. If the policy rule responds strongly to deviations from the inflation target, the aggregate demand curve is relatively flat whereas a strong response to the output gap makes for a steep aggregate demand curve. If we retain equations (8) and (9) to model the dynamics of inflation, we get (for any given $\bar{y}$ )

$$
d \pi / d t=\varepsilon_{1} d y / d t+\varepsilon_{1} \zeta(y-\bar{y})
$$


We can eliminate $d y / d t$ from (14) by noting that $d y / d t$ must be equal to $-\theta_{1} d \pi / d t$ as the economy moves along the aggregate demand curve (13'). Equation (14) can thus be rewritten as

(14') $\quad d \pi / d t=\frac{\varepsilon_{1} \zeta}{1+\varepsilon_{1} \theta_{1}}(y-\bar{y})$.

Together, equations (13') and (14') fully describe the behavior of output and inflation under the regime of a Taylor rule. The equilibrium of the system is given by $y=\bar{y}$ and $\pi=\pi_{T}$ and it is stable as indicated by the arrows pointing to the equilibrium $E_{0}$ in Figure 2. To verify that the equilibrium inflation rate is indeed equal to the target rate $\pi_{T}$, we have to make use of the definitions of $\theta_{0}$ and $\theta_{l}$, above, as well as of the fact that the equilibrium real interest rate $\hat{r}$ satisfies the IS condition (5) for $y=\bar{y}$. Moreover, the central bank must be able to estimate both the level of natural output and the equilibrium real interest rate in a reliable way. If the policy rule is based on erroneous estimates of these equilibrium concepts, the central bank will miss its inflation target. ${ }^{10}$

Figure 2

What is responsible for the much better stability properties of the equilibrium in Figure 2 as compared to the equilibrium in Figure 1? A key feature of the Taylor rule is a strong interest rate response to inflation. For every percentage point by which the inflation rate rises, the rule instructs the central bank to raise the nominal interest rate by $1+\eta_{l}$ percentage points. By following this instruction, monetary policy automatically prevents the destabilizing real interest rate effect which Keynes feared would result from "slowly sagging moneywages".

Figure 2 also sketches the effects of wage restraint when monetary policy follows the Taylor rule. $P C_{0}$ is the short run Phillips curve crossing the demand schedule $A D_{0}$ at the initial equilibrium point $E_{0}$ where both expected and actual inflation are equal to the target rate $\pi_{T}$. Wage restraint, defined again as an increase in the parameter $\varepsilon_{0}$ in equation (8), shifts the short run Phillips curve from $P C_{0}$ to $P C_{1}$ and raises natural output from $\bar{y}_{0}$ to $\bar{y}_{1}$. What this does to inflation and output depends, of course, on the response of monetary policy. Taken literally as specified above, the Taylor rule calls for the central bank not just to observe inflation and adjust the interest rate accordingly, but also to readjust the

${ }^{10}$ Hall (2000) demonstates that, in the past four decades, changes in the equilibrium real interest rate and the natural unemployment rate have been important sources of shifts in an optimal monetary policy rule for the United States. 
parameters of its reaction function with a view to the changed equilibrium levels of real output and the real interest rate. If this is what the central bank actually does, it is straightforward to show that the $A D$ curve must shift rightwards just as far as the short-run Phillips curve (i.e. to $A D_{l}$ ). In this case, the central bank accommodates the wage restraint so perfectly that the economy moves directly to the new long-run output level with unchanged inflation.

This scenario asks an awful lot of the central bank, however. A more plausible characterization of how monetary policy would respond to wage moderation under a Taylor rule might start with the presumprion that the central bank chooses a more cautious approach and adjusts its reaction function only gradually as the changes in its macroeconomic environment become apparent. In terms of Figure 2 , this would mean that wage moderation at first moves the economy to point $S$ along an unchanged demand curve. Real output does not move to its new equilibrium level right away, but it still rises in the short run because the central bank responds to the fall in inflation with a lower interest rate. Over time, the central bank will notice that inflation continues to fall although output exceeds its previous equilibrium level. As a consequence, it will eventually revise its estimate of equilibrium output and dare to be more expansionary until inflation is back to its target rate. Although the transition to the new equilibrium $E_{l}$ proceeds more slowly with this more cautious approach of the central bank, it is definitely completed sooner and more directly than it could possibly be in the scenario of Figure 1 because there is no scope for any destabilizing real interest rate effects and real output moves in the right direction from the very beginning.

\section{The open economy}

In the General Theory, Keynes made only few references to open-economy considerations. One of them can be found in Chapter 19 where he pointed out that a reduction of money-wages is favorable to employment if it is a „reduction relatively to money-wages abroad" (p. 262). Also, in drawing the conclusions from his analysis of money-wage changes, he added an interesting qualification with regard to the open economy (p. 270):

"I am now of the opinion that the maintenance of a stable general level of money-wages is, on a balance of considerations, the most advisable policy for a closed system; whilst the same conclusion will hold good for an open system, provided that equilibrium with the rest of the world can be secured by means of fluctuating exchanges."

No doubt, this remark reflected his exasperation with the experience of the United Kingdom after the return to the Gold Standard when monetary policy had 
its hands tied and wages and prices were forced down under the pressure of a grossly misaligned real exchange rate.

Open-economy considerations and the role of the exchange rate regime have come to play a significant role again in present-day controversies about wages and employment. Employers, in particular, are keen to point out that rising wage costs harm employment by impairing the international competitiveness of domestic producers. However, serious doubts have been raised regarding the effectiveness of wage restraint in an open-economy context. According to one widely held view, there is no reliable link between wage restraint and international competitiveness in an economy whose exchange rate is free to fluctuate or, if pegged, subject to frequent realignments. The experience of Germany is often cited as evidence in support of this view. Ever since the breakdown of fixed exchange rates in the early 1970s, Germany kept its rate of nominal wage growth well below that of most other European economies; but what is the value of such virtue if it is systematically 'punished' by offsetting currency appreciation?

A new situation has been created with the start of the European Monetary Union (EMU) whose members have given up the exchange rate as a policy tool. Because wage changes directly affect relative competitiveness in this case, some authors have warned that EMU members might get engaged in competitive wage deflation." As every country would attempt to lower its costs in order to gain a competitive advantage, so the story goes, they would all level down their wages without getting anything in return because they would all end up with unchanged relative wages.

Space limitations preclude an explicit discussion of open-economy models suited to address these issues. However, one basic point can still be made: The logic of ,keynesian macroeconomics without the LM curve“ for an open economy with a flexible exchange rate is largely the same as for a closed economy. ${ }^{12}$ The main difference is that the transmission mechanism of monetary policy in the open economy involves the exchange rate in addition to the interest rate. But with all the necessary amendments made, the demand side can still be represented by an aggregate demand curve as in Figure 2, above, and the effects of wage restraint can therefore be analyzed in much the same way. Such an analysis shows, incidentally, that wage restraint unambiguously depreciates the real exchange rate. Thus, the presumption that changes in wage policy are offset by the induced movements of a flexible exchange rate is demonstrably wrong.

For the same reason, the alleged threat of a „,competitive wage deflation“ in the EMU does not stand up to closer scrutiny. If we accept, for the sake of the argument, the premise that the formation of EMU has intensified the competitive

\footnotetext{
"See e.g. the exchange between Kromphardt, Theise, Schulten and Schürfeld on the threat of widespread "wage dumping" in the EMU; in Wirtschaftsdienst II/1999.

${ }^{12}$ See Romer (1999) or, for an empirical model of an open economy with a monetary policy rule, Ball (1999).
} 
pressure on national wage setters, the result is more moderate wage increases in the monetary union as a whole. If we further assume that the European Central Bank has a monetary reaction function roughly resembling the Taylor rule, the implications should by now be clear: The interest rate will be allowed to fall (ceteris paribus) so as to prevent the inflation rate from falling too far below the central bank's target rate. ${ }^{13}$ This in turn creates scope for an expansion of output and employment. The „competitive wage deflation“ hypothesis errs in assuming that wage restraint can engender positive employment effects only to the extent that it can create favorable international cost differentials when in fact its main impact is through the induced relaxation of monetary conditions.

\section{Conclusion}

The relative roles and responsibilities of wage and demand policies for the evolution of unemployment remain controversial. Those who reject wage restraint as a cure for unemployment are prone to invoke Keynes in support of their views. Indeed, a number of issues debated nowadays with regard to the effects of wage policy can be traced back to Chapter 19 of the General Theory. This paper has reconsidered some of these issues in the context of alternative keynesian models. Its main findings can be summed up as follows:

1. Adding a purchasing power effect of wage changes to an otherwise standard keynesian model cannot reverse the sign of the employment effect of a wage change. Because the purchasing power of wage earners depends as much on employment as on wages, the purchasing power effect acts more like a multiplier, strengthening the effects that arise through other channels.

2. In a natural rate model, the real interest rate effects of gradual wage and price adjustment destabilize the economy if the central bank is targeting a monetary aggregate. In such a setting, wage flexibility is of dubious value.

3. If, instead, monetary policy is guided by a feedback rule of the type proposed by Taylor, the favorable employment effects of wage restraint materialize much more reliably and with less delay.

4. These results apply to an open-economy context as well as to a closed system. In particular, the view that a flexible exchange rate undermines the effectiveness of wage policy is wrong. So is the notion that wage restraint in a monetary union leads to fruitless competitive wage deflation.

Conclusion: Keynes was right to argue that the stabilization of a market economy near full employment cannot safely be left to market-driven wage and

${ }_{13}$ The complications that arise if the interest rate hits a lower limit (i.e. a liquidity trap) cannot be taken up here; see Krugman (1998) and Svensson (2000), however, for recent discussions of this case. 
price adjustment alone. His skepticism was well-founded by the experience of his time when monetary policy was paralyzed defending a misaligned exchange rate and the overall stance of demand policy was crassly deflationary. However, in an environment of enlightened monetary policy rules, none of the effects of Chapter 19 can be used as an excuse for rejecting wage restraint and labor market flexibility as a major precondition of sustainable low unemployment.

\section{References}

Ball, L. (1999), Policy Rules for Open Economies. In: Taylor, J.B. (ed.), Monetary Policy Rules. Chicago, 127-44.

Bernanke, B.S., Mihov, I. (1997), What Does the Bundesbank Target?, European Economic Review 41, 1025-53.

Clarida, R., Gertler, M. (1997), How the Bundesbank Conducts Monetary Policy. In: Romer, C.D., Romer, D.H. (eds.), Reducing Inflation: Motivation and Strategy. Chicago, 363-406.

Friedman, M. (1968), The Role of Monetary Policy, American Economic Review 58, 1-17.

Gordon, R.J. (1996), Macroeconomic Policy in the Presence of Structural Maladjustment. In: OECD, Macroeconomic Policies and Structural Reform. Paris, 173-203.

Hall, R.E. (2000), Monetary Policy with Changing Financial and Labor-Market Fundamentals, Stanford University.

Jerger, J., Landmann, O. (forthcoming), Lohnhöhe, Güternachfrage und Beschäftigung, forthcoming in WIST - Das Wirtschaftsstudium.

Keynes, J.M. (1936), The General Theory of Employment, Interest, and Money, London.

Krugman, P. (1998), It's Baaack: Japan's Slump and the Return of the Liquidity Trap, Brookings Papers on Economic Activity 2, 137-87.

Laidler, D., Parkin, M. (1975), Inflation: A Survey, Economic Journal 85, 741809. 
Landmann, O., Jerger, J. (1999), Beschäftigungstheorie. Berlin, Heidelberg, New York.

Patinkin, D. (1948), Price Flexibility and Full Employment, American Economic Review 38, 543-65.

Phelps, E.S. (1967), Phillips Curves, Inflation Expectations, and Optimal Employment over Time, Economica 34, 254-81.

Romer, D. (1999), Short Run Fluctuations. University of California, Berkeley.

Romer, D. (2000), Keynesian Macroeconomics without the LM Curve, Journal of Economic Perspectives 14, 149-69.

Svensson, L. (2000), The Zero Bound in an Open Economy: A Foolproof Way of Escaping from a Liquidity Trap, CEPR Discussion Paper 2566, September.

Taylor, J.B. (1993), Discretion versus Policy Rules in Practice, CarnegieRochester Conference Series on Public Policy 39, 195-214.

Taylor, J.B., ed., (1999), Monetary Policy Rules. Chicago.

Tobin, J. (1975), Keynesian Models of Recession and Depression, American Economic Review 65, P.P., 195-202.

von Weizsäcker, C.C. (1978), Das Problem der Vollbeschäftigung heute, Zeitschrift für Wirtschafts- und Sozialwissenschaften 98, 33-51. 


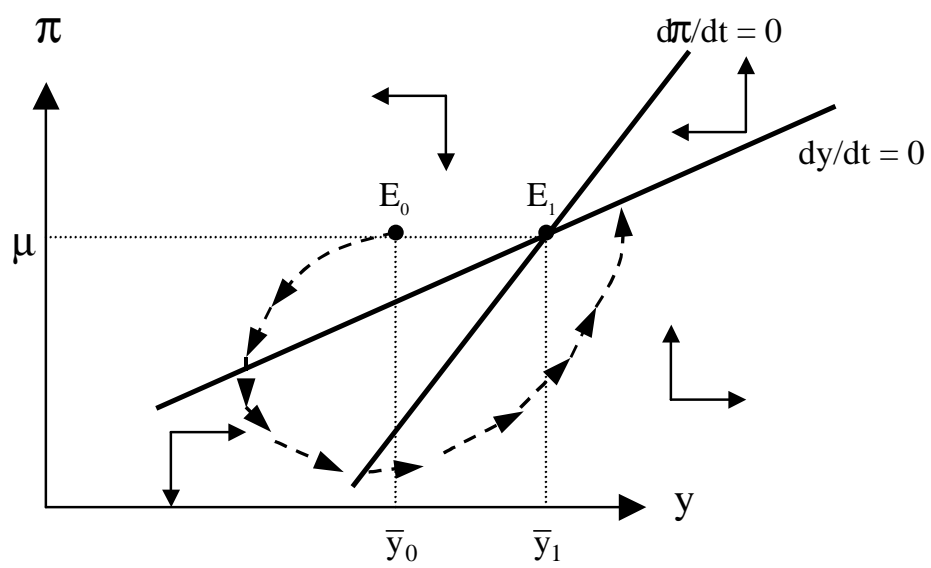

Figure 1: Wage moderation with constant money growth.

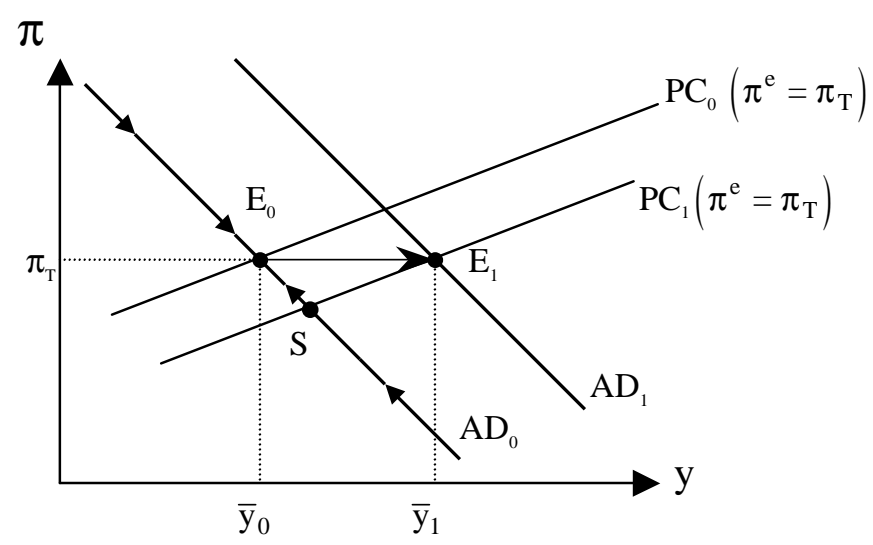

Figure 2: Wage moderation with a Taylor rule. 